\title{
Sustainability of Agriculture in Miami-Dade County: Considering Water Supply ${ }^{1}$
}

Kati W. Migliaccio²

The term sustainable agriculture is used to describe an agricultural production system that is not only economically profitable, but also environmentally friendly. The concept of sustainability has grown out of the desire to leave our environment in a good condition for future generations. Although many different factors influence agricultural sustainability, one major factor is irrigation.

Irrigation is essential to most agricultural production systems and has been shown to significantly increase yield (National Research Council, 1996). Florida agricultural irrigation accounts for more than 3,900 million gallons per day (MGD) or $48 \%$ of all ground and surface freshwater withdrawals. This is not surprising, because over 1.8 million acres of agricultural land in Florida are irrigated (National Agricultural Statistic Service, 2007).

The relationship between irrigation and agricultural sustainability is both economic and environmental. Irrigation, when implemented properly, can increase yield and reduce agrochemical requirements, ultimately increasing profit. Irrigation implemented incorrectly may result in overuse of water (Muñoz-Carpena and Dukes, 2005), loss of agrochemicals (Spalding et al., 2001), and possibly decreased yield or harvest quality (Phene and Howell, 1984; Wang et al., 2002; 2005).

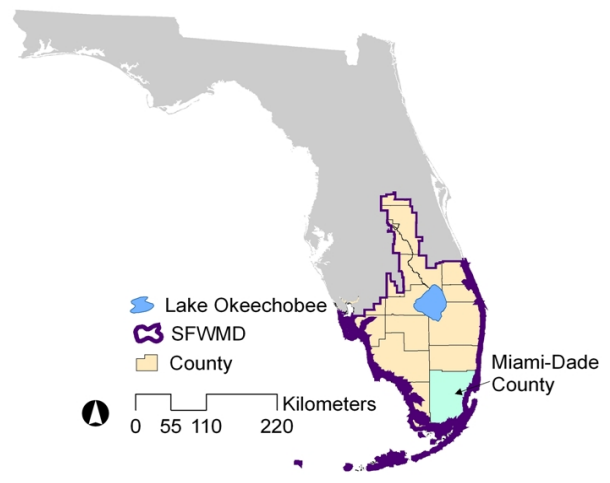

Figure 1. The South Florida Water Management District boundary and Miami-Dade County FL. Credits: K.W. Migliaccio

Developing sustainable agricultural practices in Miami-Dade County (Figure 1) is important to ensuring the future of its economically significant winter vegetable, tropical fruit, and ornamental nursery plant production. This publication discusses water availability, factors that influence water

1. This document is ABE 380, one of a series of the Department of Agricultural and Biological Engineering, Florida Cooperative Extension Service, Institute of Food and Agricultural Sciences, University of Florida. First printed: August 2007. Please visit the EDIS Web site at http://edis.ifas.ufl.edu

2. Kati W. Migliaccio is Assistant Professor, Tropical Research and Education Center (TREC), Homestead, FL, Cooperative Extension Service, Institute of Food and Agricultural Sciences, University of Florida, Gainesville, 32611.

The Institute of Food and Agricultural Sciences (IFAS) is an Equal Opportunity Institution authorized to provide research, educational information and other services only to individuals and institutions that function with non-discrimination with respect to race, creed, color, religion, age, disability, sex, sexual orientation, marital status, national origin, political opinions or affiliations. U.S. Department of Agriculture, Cooperative Extension Service, University of Florida, IFAS, Florida A. \& M. University Cooperative Extension Program, and Boards of County Commissioners Cooperating. Larry Arrington, Dean 
availability, agricultural water use, and irrigation efficiency as they relate to Miami-Dade County.

\section{Water Availability}

In order to irrigate, agricultural producers must have a reliable and usable source of water. In Miami-Dade County, the dominant freshwater source is the Biscayne aquifer (Figure 2). Producers rely on this water supply not only for irrigation, but also for the protection of crops against freezing when temperatures occasionally drop below freezing in the winter. The Biscayne aquifer is also used as the primary drinking water supply for about 3 million people.

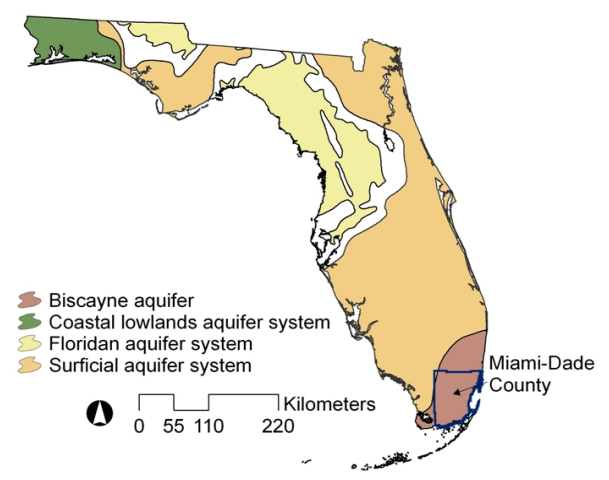

Figure 2. Uppermost principle aquifers for Florida from USGS Water Resources Division, 1998. Credits: K.W. Migliaccio

The Biscayne aquifer is an underground unconfined system of limestone, sandstone, and sand that stores ground water (Klein and Hull, 1978). It is also fairly shallow, highly permeable, and hydraulically connected to both fresh and salt waters. These three aspects make the protection of the aquifer from salt water intrusion challenging. Protection of the aquifer requires a volume of fresh water (also known as freshwater head) to be maintained; lowering of this freshwater volume results in saltwater intrusion into the aquifer, rendering the water in the aquifer unfit for drinking and irrigating (Miller, 1990).

Because of the high permeability of the surrounding soil and limestone bedrock as well as the close proximity of the aquifer to the ground surface, the Biscayne aquifer is highly susceptible to ground-water contamination. The quality of water in the aquifer can be degraded by various human pollutants including fertilization, septic tanks, chemical spills, and other sources. Pollutants are transported by rainfall or irrigation through the soil profile and into ground water supplies (Bradner et al., 2004). The importance of high-quality water in the Biscayne aquifer is crucial, as contamination of the aquifer could result in its inability to be used as a drinking water supply (without expensive treatment) and possibly as an irrigation supply.

The Biscayne aquifer has been a dependable source of water supply. Because of this, the availability of water for irrigation has not historically been a dominant concern for agricultural producers in Miami-Dade County. However, the demands on and variability in our water supplies have intensified tremendously over recent years in response to climate variability, rapid urbanization, and natural system protection goals (such as the Comprehensive Everglades Restoration Plan, or CERP). These factors must be balanced to ensure an adequate water supply for all water uses.

\section{Climate Variability}

Climate variability plays an important part in managing our water supplies. For this discussion, climate variability refers to a fluctuation in climate that occurs over a few months or seasons ( e.g., annual amount of rainfall, number of tropical storms per year, etc.). The most commonly reported climate variability phenomenon is the ENSO phase (or El Niño and La Niña). These fluctuations in climate influence water supplies through their deviations in temperature and/or precipitation for a period of time. Oftentimes these variabilities result in drought or other extreme events.

Most recently, the 2006-2007 drought encompassed much of the state of Florida. The drought was primarily due to record low rainfalls. Rainfall is the primary source of water for replenishing fresh surface- and groundwater reservoirs used for water supply in Florida. The 2006-2007 drought resulted in Lake Okeechobee reaching new record lows and the South Florida Water Management District (SFWMD) instating water restrictions. Water restrictions were implemented to conserve water supplies during the drought period. However, it has been suggested that 
some water restrictions will become a mainstay as the demands on water supplies continues to increase.

\section{Urbanization in South Florida}

Florida is one of the most populated states in the US and faces unique challenges in meeting the rapidly increasing demands of human water needs. In Miami-Dade County, the population has increased from 2.2 million in 2000 to an estimated 2.4 million in 2006, an approximate $6 \%$ increase in population (US Census Bureau, 2007). Approximately 175 gallons of water are used per person per day in south Florida, translating into an increased water demand of over 35 million gallons per day due to population change in Miami-Dade County between 2000 and 2006 (SFWMD, 2007).

Urbanization may also influence the water supply recharge (or refilling of the aquifer from infiltrated rainfall) and quality (Foster et al., 1998). As populations continue to grow and human needs for consumable water increase, local authorities and utilities, in conjunction with the SFWMD, will need to find solutions to the competing demands on south Florida water supplies.

\section{Natural Systems}

South Florida is rich in unique ecological systems that are biologically valuable. The Everglades has received much attention and was the world's largest restoration effort at its onset. The CERP plan for the Everglades includes restoring natural flows of water, water quality, and nearly natural seasonal water levels, which have implications for water availability (Kranzer, 2003). Restoration is being directed by the SFWMD and the US Army Corp of Engineers (USACE).

Accomplishment of these goals requires a wide assortment of projects that include modifying freshwater flows and implementing Best Management Practices (BMPs) to minimize pollutant loads entering the Everglades.

In addition to the Everglades, the Biscayne Bay and the Florida Bay estuaries are two natural ecosystems in south Florida that are of ecological importance (Figure 3). Biscayne Bay is home to an aquatic preserve which consists of northern and southern portions of the bay. The aquatic preserve is separated by the Biscayne National Park. Unlike many portions of Florida coastline, the southern portion of the estuary is one of the most pristine areas in coastal south Florida (FDEP, 2007).

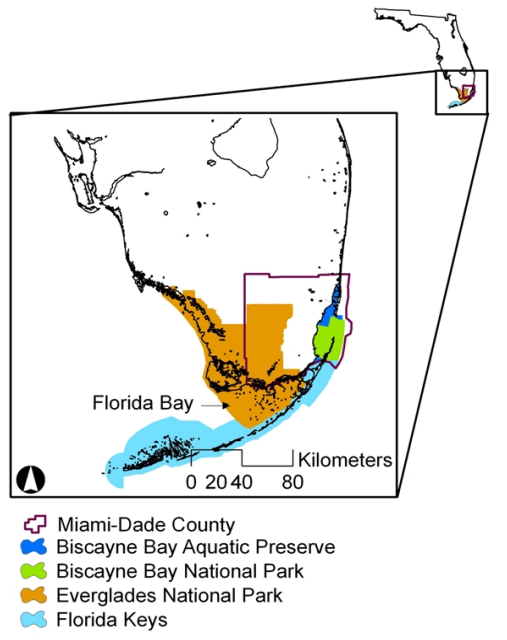

Figure 3. Location of Biscayne Bay and Florida Bay. Credits: K.W. Migliaccio

Biscayne Bay is the receiving water for much of Miami-Dade County and portions of Broward County, both of which are experiencing rapid development and population growth. This urbanization trend has resulted in several studies regarding the water quality and quantity conditions in Biscayne Bay and protection of its unique and diverse ecosystem. Most notable is the 2007 South Miami-Dade Watershed Study and Plan. The goal of this study was to provide a plan that balances all the water uses in the area, including natural systems and human quality of life.

Similar to Biscayne Bay, Florida Bay also represents a unique estuary system. The majority of Florida Bay, which is located between Florida mainland and the Florida Keys, is within the Everglades National Park (Figure 3). Florida Bay is an important ecological resource and home to a wide range of marine animals. It also supports substantial shrimp and stone crab industries (Florida Sea Grant, 2007). Florida Bay is the receiving water body for much of the southern Everglades. Hence, the CERP has implications regarding changes in how the bays receive water. 
While CERP goals strive to return water quality and quantity to more natural levels, human activities are causing considerable ecosystem stress in the Florida Bay. The delicate ecosystem balance found in the Florida Bay (and Biscayne Bay) was threatened in 2006 as an algal bloom flourished in the normally clear waters. The preservation of these natural systems depends on many factors, one of which is the quality and quantity of water inflows. The quality and quantity of inflows are influenced by natural processes and human practices. While natural processes are difficult to control, there are management practices that can be implemented to minimize human influences and preserve water quality and quantity inflows into natural systems. Best Management Practices (BMPs) have been identified and are under continual research and development for different applications.

Specifically, BMPs for agriculture have been an active area of research and implementation in Florida. Agricultural BMPs are generally commodity and regionally designated. The agricultural BMPs are designed and implemented with the objective of increasing agricultural sustainability while also protecting water resources. As the interest in preserving natural systems grows and public policies evolve to reflect this, agricultural producers are modifying their production systems to accommodate these additional goals. More information regarding the agricultural BMP program in Florida can be found at the Florida Department of Agricultural and Consumer Services (FDACS), Office of Agricultural Water Policy Web site http://www.floridaagwaterpolicy.com/AtaGlance.html

\section{Sustainable Agriculture and Irrigation}

Conservation practices and efficient water use is imperative to ensuring an adequate water supply for all users. Agricultural producers not only need to protect the water supply to ensure its uninterrupted availability and quality for future irrigation needs, but also need to balance water conservation with the economic viability of their agricultural system (i.e., agricultural sustainability). For agricultural sustainability in Miami-Dade County, it is critical that a balance between water conservation and economic agricultural production be achieved.

Irrigation of agricultural lands requires a water supply (Biscayne aquifer), a water delivery system, and an irrigation schedule. The water delivery system and the irrigation schedule used by the agricultural producer are two components of the irrigation system that may be optimized for greater agricultural sustainability.

\section{Water Delivery Systems}

For Miami-Dade County, water delivery systems are generally not a source of excessive water waste as water is pumped from ground water at the actual site of irrigation. Some inefficiencies may be present regarding large acreages where water may be piped throughout for irrigation delivery. These types of irrigation system inefficiencies may be easily remedied by conducting regular maintenance of the irrigation system. Regular maintenance consists of turning on the irrigation and observing each component of the irrigation system for proper function. Common problems are leaks around fittings, cracks/disconnects in the line (due to tractor or vehicle damage), holes in drip tape, and broken sprinkler heads. All of these malfunctions are fairly easy to identify and fix; however, they are often overlooked as irrigation timing may not be at a convenient hour for inspection and growers have many other demands on their time.

In Miami-Dade County, agricultural irrigators have the opportunity to contact the Mobile Irrigation Lab (MIL) to assist with irrigation efficiency assessments, particularly those related to the water delivery system. The MIL, historically housed with the South Dade Soil and Water Conservation Service in Florida City, FL, tests irrigation systems and identifies problems that result in wasted water. It provides a valuable service for agricultural producers by improving their irrigation efficiency and reducing wasted water, thereby increasing sustainability.

\section{Irrigation Schedules}

While the water delivery system component of an irrigation system should be considered and evaluated when targeting irrigation efficiency, 
irrigation scheduling is the central component of an irrigation system that can be modified to improve sustainability. Irrigation scheduling refers to the duration and frequency of irrigation events.

Irrigation scheduling is most commonly regulated by manual turn-on and turn-off systems or by automatic timer systems, both of which may result in over-irrigation. Manual irrigation consists of someone deciding that irrigation is needed, turning on the irrigation, and turning off the irrigation once sufficient water has been delivered. The weaknesses of such a system are that someone must be present to turn on and off the irrigation and it is easy to lose track of time or not monitor the irrigation closely and thus over irrigate. Automatic timers offset some of these weaknesses by not requiring a person to be onsite and by providing for automatic shutoff. However, use of automatic timers for controlling irrigation has other flaws. The basic concept behind automatic irrigation is that a timer is set to irrigate for a specific duration and frequency, whether or not water is needed. Over-irrigation reduces agricultural sustainability by using increased amounts of water, increasing nutrient leaching, and possibly reducing yields and agronomic profits.

Research conducted at the University of Florida Tropical Research and Education Center (UF-TREC) in Homestead, FL, and UF Gainesville has focused on implementing modified irrigation scheduling methods to increase agricultural sustainability. Research has primarily focused on implementing soil moisture sensors to initiate irrigation

(Muñoz-Carpena et al., 2005; Muñoz-Carpena and Dukes, 2005). Soil moisture based irrigation consists of a soil moisture sensing device that relays information to an automated control on whether or not irrigation is needed.

Currently, three field studies are being conducted at UF-TREC to evaluate the use of soil moisture sensors for irrigating fruit crops and ornamental nursery production. Data have been collected for over one year for three different studies: papaya, avocado, and palm nursery. All of these studies included different irrigating methods, such as typical automated irrigation, soil moisture based irrigation, and evapotranspiration (ET) based irrigation. The soil moisture based irrigation has been shown to consistently use less water for all applications (85 to 95\% less than traditional automated systems) and has also resulted in no significant decreases in production yields.

Soil moisture based irrigation is being conducted using switching tensiometers (Irrometer ${ }^{\circledR}$ Co., Riverside, CA, Figure 4). Switching tensiometers are devices that can be installed in the field to measure soil tension (or suction). This measurement is then compared to a setting that is adjusted by the user. The switching tensiometer functions as a switch that closes (or allows the solenoid to open and irrigation to occur) when the soil moisture tension is greater than the user-specified setting. However, tensiometers are only one of many available technologies that can be used to estimate soil moisture and initiate irrigation (Muñoz-Carpena, 2004).

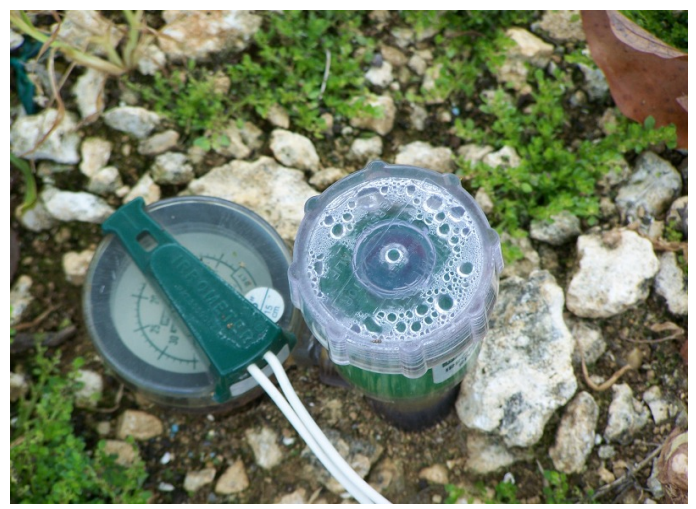

Figure 4. Switching tensiometer. Credits: $\mathrm{H}$. Trafford

Research at the UF-TREC on irrigation and sustainability is ongoing. As new technologies become available, they will be integrated into laboratory and field trials to ensure that agricultural producers in Miami-Dade County have the most relevant and up-to-date information. UF extension specialists and agents are also continually working with agricultural producers to ensure that new technologies and research products are feasible and meet the needs of producers. Continued interaction among extension faculty, extension agents, and growers is essential for increasing the sustainability of agriculture in Miami-Dade County. 


\section{Summary}

An important component of a sustainable agricultural system is irrigation. The ability of agricultural production to successfully continue in Miami-Dade County will depend on the availability of water for irrigation. Due to the increasing demands on water supplies and uncertainties related to climate variability, greater efforts are being made to conserve water by implementing BMPs for agricultural crops. One promising BMP that has been shown to conserve considerable amounts of water when implemented in Miami-Dade County is the use of soil moisture measuring devices to initiate irrigation. Agricultural sustainability will benefit from continued development of irrigation BMPs to be used in agricultural production.

\section{References}

Bradner, A., B.F. McPherson, R.L. Miller, G. Kish, and B. Bernard. 2004. Quality of ground water in the Biscayne aquifer in Miami-Dade, Broward, and Palm Beach Counties, Florida, 1996-1998, with emphasis on contaminants. US Geological Survey Open-File Report 2004-1438, 20p.

ERS (Economic Research Service), 2007. State fact sheets: Florida. USDA-ERS Web site http://www.ers.usda.gov/StateFacts/FL.HTM

FDEP (Florida Department of Environmental Protection), 2007. FDEP Web site http://www.dep.state.fl.us/coastal/sites/biscayne/ info.htm

Florida Sea Grant, 2007. Florida Sea Grant Web site http://www.floridabay.org/intro.shtml

Foster, S., A. Lawrence, and B. Morris. 1998. Groundwater in Urban Development: Assessing Management Needs and Formulating Policy Strategies. World Bank Technical Paper No. 390. The World Bank: Washington, D.C.

Hester, R.E. and R.M. Harrison. 2005. Sustainability in Agriculture. Royal Society of Chemistry: Cambridge, UK.
Klein, H. and J.E. Hull. 1978. Biscayne Aquifer, Southeast Florida. US Geological Survey Water-Resources Investigations Report 78-107.

Kranzer, B. 2003. Everglades restoration: interactions of population and environment. Population and Environment 24(6):455-484.

Miller, J.A. 1990. Ground water atlas of the United States: Alabama, Florida, Georgia, and South Carolina. HA 730-G US Geological Survey. http://capp.water.usgs.gov/gwa/ch_g/index.html

Muñoz-Carpena, R. 2004. Field devices for monitoring soil water content. Bulletin 343, Agricultural and Biological Engineering Department, Florida Cooperative Extension Service, Institute of Food and Agricultural Sciences, University of Florida. http://edis.ifas.ufl.edu/AE266

Muñoz-Carpena, R. and M. Dukes. 2005. Automatic irrigation based on soil moisture for vegetable crops. ABE356, Agricultural and Biological Engineering Department, Florida Cooperative Extension Service, Institute of Food and Agricultural Sciences, University of Florida. http://edis.ifas.ufl.edu/AE354

Muñoz-Carpena, R., Y.C. Li, and T. Olczyk. 2005. Alternatives of low cost soil moisture monitoring devices for vegetable production in south Miami-Dade County. ABE333, Agricultural and Biological Engineering Department, Florida Cooperative Extension Service, Institute of Food and Agricultural Sciences, University of Florida. Original publication date October 2002. Reviewed December 2005. http://edis.ifas.ufl.edu/AE230

National Research Council, 1996. A New Era for Irrigation. National Academy Press: Washington, D.C.

Phene, C.J. and T.A. Howell. 1984. Soil sensor control of high-frequency irrigation systems. Transactions of the ASAE 27(2):392-396.

SFWMD (South Florida Water Management District), 2007. Water supply. www.sfwmd.gov

Spalding, R.F., D.G. Watts, J.S. Schepers, M.E. Burbach, M.E. Exner, R.J. Poreda, and G.E. Martin. 2001. Controlling nitrate leaching in irrigated 
agriculture. Journal of Environmental Quality

30:1184-1194.

US Census Bureau. 2007. Census Bureau State and County QuickFacts.

http://quickfacts.census.gov/qfd/index.html

Wang, Q., H. Bryan, A. Abdul-Baki, W.

Klassen, Y. C. Li, and M. Codallo. 2002. Improved Tomato Production with Summer Cover Crops and Reduced Irrigation Rates.Proc. Fla. State Hort. Soc. 115:202-207.

Wang, Q., W. Klassen, Y. Li, M. Codallo, and A.A. Abdul-Baki. 2005. Influence of Cover Crops and Irrigation Rates on Tomato Yields and Quality in a subtropical Region. HortScience 40 (7): 2125-2131. 